\title{
English Department Students' Experience and Opinions on the Use of Podcast for Learning English Independently
}

\section{Pengalaman dan Pendapat Mahasiswa Jurusan Sastra Inggris Mengenai Penggunaan Podcast untuk Belajar Bahasa Inggris secara Mandiri}

\author{
Alvi Rosyidah, Furaidah*. Nunung Suryati \\ Universitas Negeri Malang, Jl. Semarang No. 5 Malang, Jawa Timur, Indonesia \\ *Penulis korespondensi, Surel: furaidah.fs@um.ac.id
}

Paper received: 02-01-2021; revised: 15-01-2021; accepted: 30-01-2021

\begin{abstract}
This study examined ELE students' experience and opinions on the use of podcasts for learning English independently. It employed surveys as the research method with a questionnaire as the research instrument. The respondents were 212 students of English Language Education major of Universitas Negeri Malang from the cohorts of 2016-2020. The data gathered from the questionnaire were then analyzed by using frequency distribution, and accumulated in the form of percentages denoting every student's responses for every item. From the percentages, the numbers were then elaborated into sentences with descriptive analysis. The finding showed that most of the students used podcasts more for improving their language systems, speaking and listening skills, rather than for improving their reading and writing skills. The majority of the respondents also held positive opinions towards the use of podcasts as an adequate complementary tool for learning English independently. The characteristics of podcasts that the students found most appealing were due to its portability, simplicity, enjoyability, accessibility, and the various range of interesting topics to learn. Also, it featured a concise wrap of information, meaningful context, and provided a chance to listen to authentic materials provided by native speakers.
\end{abstract}

Keywords: students' experience, students' opinions, podcast, learning English, independent learning

\begin{abstract}
Abstrak
Penelitian ini didasari oleh konflik psikologis karena peristiwa kecelakaan yang dialami Tokoh Terry sehingga menyebabkan trauma. Kasus tersebut tercermin dalam sebuah novel yang berjudul Janji Pelangi karya Fahrul Khakim. Tujuan dari penelitian ini adalah untuk mendeskripsikan tipe trauma, respon trauma, dan struktur kepribadian id, ego, dan superego tokoh Terry. Metode dalam penelitian ini adalah kualitatif dengan jenis penelitian analisis teks yang dikaji melalui psikologi sastra. Teknik pengumpulan data dilakukan dengan cara membaca, menyimak, dan mencatat. Hasil penelitian ini meliputi tiga hal, pertama adalah tipe trauma ada 8 data yang terbagi atas empat tipe, yaitu trauma situasional karena kecelakaan, trauma perkembangan karena penolakan teman sebaya, trauma intrapsikis karena kecemasan, dan trauma eksistensial karena kekurangberartian. Kedua, respons trauma ada 44 data yang terbagi menjadi empat respons, yaitu respons emosional yang berindikator malu, bergejolak, dan panik. Selanjutnya, respons kognitif yang berindikator berpikir tak sanggup, merepotkan, dan mimpi buruk. Kemudian, respons perilaku berindikator mengurung diri, dan nafsu makan menurun. Lalu, respons fisiologis berindikator pucat pasi, wajah pilu, dan kurus. Ketiga, terdapat 56 data yang masing-masing sebagai berikut, Id memiliki subaspek yang meliputi naluri kehidupan, naluri kematian, dan kecemasan. Berikutnya, ego mempunyai sub aspek represi, projeksi, dan regresi. Kemudian, superego meliputi moralitas dan mengejar kesempurnaan.
\end{abstract}

Kata kunci: pengalaman dan pendapat mahasiswa, podcast, belajar Bahasa Inggris, pembelajaran mandiri 


\section{Intraoduction}

Podcast is one of the media developed as a result of the advancement of technology that has potential for language learning. Darwis (2016) maintained that lots of teachers around the world occasionally utilize podcasts in their learning and teaching activities. It is used with such consciousness to help their students' learning, as it has been proved as an effective tool in learning English. However, it is not really a familiar tool for most of Indonesian students for independent English learning. Many of them are still not aware of the efficacy of podcasts as English learning media. They might have used podcasts for enjoyment or pleasure, but some of them are not aware that it can also be useful for learning English independently.

As a form of media, podcasts carry numerous benefits for language learning. It allows learners to experience some features that other language learning media do not typically provide. Some of them are the features of transcriptions, pre-listening exercises, whilstlistening exercises, post-listening exercises, answer key, glossary, further resources relating to the subject or topic, and some other benefits regarding its portability, flexibility, and practicality.

Several studies regarding podcasts have been developed. The majority of the literature concerning the use of podcasts in English learning only examined students' perception or attitude towards podcasts for only one specific aspect of English skills or language systems. One research focusing on all English skills and language systems is a study conducted by Norhayati and Jayanti (2020). It focused on students' opinion on the use of podcasts for learning English independently. It is a case study involving 67 students from five universities in Palangkaraya. This study, however, is a survey study involving a big number of respondents conducted on university students of English Language Education program at Universitas Negeri Malang.

A few issues need to be pointed out in relation to this research. The first one is that this study was conducted in only one major of a single educational institution, namely English Language Education major. Different results might appear if it is conducted in different majors, faculties, educational institutions, and other geographical areas. Students from different places and majors might have different experiences and opinions about learning English using podcasts. The second limitation is regarding the sample size. The smaller or larger sample size might affect the accumulation of the result differently. These will be considered in the present study.

\section{Method}

The present study is conducted as a descriptive research, using a survey as the main instrument. This research is conducted in an educational institution, Universitas Negeri Malang, involving the English Language Education (ELE) students as participants. They were from five cohorts, i.e., 2020, 2019, 2018, 2017 and 2016 cohorts. The minimum quota of respondents was 140 gained from the formula of $20 \%$ of total population of ELE program students at Universitas Negeri Malang, the total number of which was estimated to be 700 students. Therefore, the minimum quota for each cohort is 28 . This was settled by using quota sampling technique which is a type of non-probability sampling technique, where a quota is set for a group representing population.

The final number of respondents was 212 students, consisting of 53 students from the 2020 cohort, 40 students from the 2019 cohort, 30 students from 2018 cohort, 35 students 
from 2017 cohort, and 54 students from the cohort of 2016. This study was conducted for seven days starting from the 25th of November until the 1st of December 2020. This period of time was set with the expectation for the number of respondents exceeding the minimum quota settled previously.

The research data was collected by using a questionnaire. Before it was administered, the questionnaire was validated by an expert. After the questionnaire was validated, it was piloted to 8 students of the ELE program, some of whom participated again in the real study. The beta version of the questionnaire was sent to these 8 people through WhatsApp Messenger. They were asked to give comments in regards to the content of the questionnaire. It aimed to know whether or not the questions of the questionnaire are clear and fathomable to the students and ready to be distributed for data collection.

After the questionnaire was ready to be distributed, it was rebuilt in Google Form and administered through WhatsApp groups for the target sample on 25th of November 2020. The use of online questionnaires through Google Form was considered more effective and efficient than the paper-based one, since all students are digital natives who know how to operate techbased questionnaires. Besides, this study was conducted during the pandemic of COVID-19, so the use of online questionnaires was considered fitting the circumstance really well. The respondents got seven days to fill in the questionnaire.

The questionnaire was adapted and went through a great deal of modification in order to meet the research objective. The questionnaire was adapted from some studies, for example Rahimi and Katal (2012), Farshi and Mohammadi (2013), Asoodar, Marandi, Vaezi, and Desmet (2014) and Zahan Chowdhury and Haque (2019). The adaptations were made to specify or paraphrase questions to be more specific and understandable; as well as omitting questions that are not relevant, and adding relevant questions to the subject of the research.

Since the subjects were intended to be students from ELE major, the questionnaire was constructed in English. The questionnaire was divided into two parts. The first part was demographic questions including name, cohorts, Student Identification Number and information on WhatsApp number. The second part is questions constructed from the variables, for example about students' experience and opinions on the use of podcasts for learning English independently. From the two variables, 45 questions were constructed. Questions number 1-14 focused on the first variable, whereas questions number 15-45 were related to the second variable. All questions were designed to use rating or Likert scales.

The collected data was then analyzed by using frequency distribution of descriptive statistics presented in graphs. The graphs informed about the thorough responses from the raw data for further analyses and put into percentages. Next, the interpretation of the percentages can be processed. Data analysis was conducted in several steps. The demographical data was analyzed first. This involved all the responses towards the questions from the first part of the questionnaire. The respondents' cohorts were tabulated and charted. This was aimed to disclose the number of respondents who are part of certain cohorts participating in this research.

The second step was analyzing the second part of the questionnaire that involved responses about students' experience and opinions on using podcasts for learning English independently. Here, the percentage of the responses for each statement was calculated. Since 
each item covered the value of $1,2,3$, or 4 (with the description as shown in the questionnaire notes), the percentage of each item was then summarized as the respondents' positive or negative attitudes to the items in the questionnaire. The positive attitudes were covered in value 3 and 4 , while the negative ones were covered in value 1 and 2 . The responses from each number were then tabulated, charted and analyzed. Finally, the tabulated data in the form of percentages was elaborated into paragraphs. Here, the meaning of numbers, diagrams, and graphs were explained for easy reading and drawing conclusions

\section{Finding and Discussion}

The section is divided into two broad categories, namely students' experience and opinions of using podcasts for learning English independently. The findings section focuses on the description of the data analysis. The interpretation, on the other hand, is presented in the discussion section.

\subsection{Students' Experience on Using Podcast for Learning English Independently}

The first part of the questionnaire concerned the participants' experience on using podcasts for learning English independently. The result of the questionnaire shows that almost all respondents tend to listen to podcasts for enjoyment. This implies that they listen to podcasts by their own will, since they enjoy doing it. The results of the following statements also supported it, since it shows that only few respondents made an effort to do the tasks following the episodes of the podcasts. This result is presented in Table 1.

Table 1. Result of Students' Preference on Using Podcast in General

\begin{tabular}{lcccc}
\hline \multirow{2}{*}{\multicolumn{1}{c}{ Item Description }} & \multicolumn{4}{c}{ Attitude } \\
\cline { 2 - 5 } & \multicolumn{2}{c}{ Positive } & \multicolumn{2}{c}{ Negative } \\
\cline { 2 - 5 } & $\mathrm{f}$ & $\%$ & $\mathrm{f}$ & $\%$ \\
\hline I listen to podcast for fun. & 192 & 90.6 & 20 & 9.4 \\
\hline $\begin{array}{l}\text { I listen to podcast while doing other things (like } \\
\text { driving, cycling, cooking, painting, jogging, etc.). }\end{array}$ & 122 & 57.5 & 90 & 42.5 \\
\hline $\begin{array}{l}\text { I use pre-listening and post listening activities on } \\
\text { podcast. }\end{array}$ & 89 & 42 & 123 & \multirow{2}{*}{58} \\
\hline I use transcription feature on podcast. & 98 & 46.2 & 114 & 53.8 \\
\hline
\end{tabular}

Next, Table 2 shows a significant number of respondents agreed and disagreed on specific parts in the questionnaire. Statements related to language systems reached the highest rate with most respondents agreeing on them. On the other hand, only few respondents agreed on the statements related to practicing speaking and making a speaking portfolio by using podcasts. From here, it is safe to say that almost all of the respondents were aware of the impact of using podcasts on the improvement of their language systems. However, only few of them literally made use of podcasts for their speaking practice, either by recording their own voice or creating an online speaking portfolio. These two points need to be highlighted since it would be affiliated with the next part of the questionnaire. 
Table 2. Result of Students' Experience on Using Podcast in Learning English Skills and Language Systems

\begin{tabular}{|c|c|c|c|c|}
\hline \multirow{3}{*}{ Item Description } & \multicolumn{4}{|c|}{ Attitude } \\
\hline & \multicolumn{2}{|c|}{ Positive } & \multicolumn{2}{|c|}{ Negative } \\
\hline & $f$ & $\%$ & f & $\%$ \\
\hline I listen to podcast as an extensive listening. & 166 & 78.3 & 46 & 21.7 \\
\hline I listen to podcast for audiobooks. & 125 & 59 & 87 & 41 \\
\hline I listen to podcast to enlarge my vocabulary. & 188 & 88.7 & 24 & 11.3 \\
\hline $\begin{array}{l}\text { I use podcast to improve my grammar } \\
\text { use/competence. }\end{array}$ & 167 & 78.8 & 45 & 21.2 \\
\hline $\begin{array}{l}\text { I listen to podcast to check and improve my } \\
\text { pronunciation, intonation, stress, etc. }\end{array}$ & 194 & 91.5 & 18 & 8.5 \\
\hline $\begin{array}{l}\text { I use podcast to record my own voice to practice } \\
\text { speaking. }\end{array}$ & 111 & 52.4 & 101 & 47.6 \\
\hline I use podcast to make portfolio of my own recording. & 69 & 32.5 & 143 & 67.5 \\
\hline $\begin{array}{l}\text { I listen to podcast also to improve and train the other } \\
\text { receptive skill (reading). }\end{array}$ & 147 & 69.3 & 65 & 30.7 \\
\hline I use podcast to look for ideas for my writing. & 138 & 65.1 & 74 & 34.9 \\
\hline I use podcast to improve my writing. & 128 & 60.4 & 84 & 39.6 \\
\hline
\end{tabular}

\subsection{Students' Opinions on the Use of Podcast for Learning English Independently}

The next part of the questionnaire was related to participants' opinions of using podcasts for learning English independently. Table 3 presents information on this aspect. It can be seen that the lowest point is no less than $76 \%$ and the statements with more than $90 \%$ of agreeability dominating the result. Overall, most of the respondents agreed that the characteristics, service, and quality of podcasts made them fond of podcasts.

Table 3. Result of Students' Opinion on the use of Podcast in General

\begin{tabular}{lcccc}
\hline & \multicolumn{4}{c}{ Attitude } \\
\cline { 2 - 5 } \multicolumn{1}{c}{ Item Description } & \multicolumn{2}{c}{ Positive } & Negative & $\%$ \\
\cline { 2 - 5 } & $\mathrm{f}$ & $\%$ & 11 & 5.2 \\
\hline Podcast is portable and easy to use. & 197 & 92.2 & 15 & \multirow{2}{*}{7.1} \\
\hline $\begin{array}{l}\text { It is enjoyable, so it helps learning not to be } \\
\text { boring. }\end{array}$ & 192 & 90.6 & 20 & \multirow{2}{*}{9.4} \\
\hline $\begin{array}{l}\text { It provides interesting diverse themes that meet } \\
\text { my interests. }\end{array}$ & 169 & 79.7 & 43 & 20.3 \\
\hline $\begin{array}{l}\text { It is a kind of unconscious learning if I listen to it } \\
\text { while focused on doing something else. }\end{array}$ & 193 & 91 & 19 & 9 \\
\hline It provides concise presentation of information. & 205 & 96.7 & 7 & 3.3 \\
\hline It is flexible, I can access it anywhere and anytime. & 164 & 77.4 & 48 & 22.6 \\
\hline It matches my learning style and preference. & 196 & 92.5 & 16 & 7.5 \\
\hline It provides meaningful context. & 190 & 89.6 & 22 & 10.4 \\
\hline $\begin{array}{l}\text { The way the information is arranged in the } \\
\text { podcasts helped keep my attention. }\end{array}$ & 162 & 76.4 & 50 & 23.6 \\
\hline $\begin{array}{l}\text { I can listen to it repeatedly. } \\
\text { It provides a chance of listening to authentic } \\
\text { materials provided by native speakers. }\end{array}$ & 207 & 97.6 & 5 & 2.4 \\
\hline
\end{tabular}

The percentage of agreeability reached more than $94 \%$ for each question. This shows the strong positive opinions on the use of podcasts for learning language systems. It is supported by the previous part of the questionnaire result implying students' strong awareness towards the benefit of using podcasts for improving their language systems. 
Table 4. Result of Students' Opinion on the use of Podcast in Learning Language Systems

\begin{tabular}{lcccc}
\hline \multirow{2}{*}{\multicolumn{1}{c}{ Item Description }} & \multicolumn{4}{c}{ Attitude } \\
\cline { 2 - 5 } & \multicolumn{2}{c}{ Positive } & \multicolumn{2}{c}{ Negative } \\
\cline { 2 - 5 } & $\mathrm{f}$ & $\%$ & $\mathrm{f}$ & $\%$ \\
\hline It can help me improving my pronunciation. & 206 & 97.2 & 6 & 2.8 \\
\hline It can help me broaden my vocabulary. & 204 & 96.2 & 8 & 3.8 \\
\hline $\begin{array}{l}\text { It trains me to make inferences or guess for the words } \\
\text { I don't know the meaning of. }\end{array}$ & 201 & 94.8 & 11 & 5.2 \\
\hline It exposes me to natural English expressions. & 200 & 94.3 & 12 & 5.7 \\
\hline It helps me to get used to natural flow of speech. & 202 & 95.3 & 10 & 4.7 \\
\hline
\end{tabular}

The result of the questionnaire as shown in Table 5 regarding students' opinion on the use of podcasts in learning listening skill shows that the majority of the respondents believe that by listening to podcasts, they can improve their listening skills.

Table 5. Result of Students' Opinion on the use of Podcast in Learning Listening Skill

\begin{tabular}{lcccc}
\hline \multirow{2}{*}{ Item Description } & \multicolumn{3}{c}{ Attitude } \\
\cline { 2 - 5 } & \multicolumn{2}{c}{ Positive } & \multicolumn{2}{c}{ Negative } \\
\cline { 2 - 5 } & $\mathrm{f}$ & $\%$ & $\mathrm{f}$ & $\%$ \\
\hline $\begin{array}{l}\text { As I listen to podcasts, I feel that I can understand } \\
\text { long utterances/conversation/monologue much better. }\end{array}$ & 186 & 87.7 & 26 & 12.3 \\
\hline It enhances my skills of listening. & 202 & 95.3 & 10 & 4.7 \\
\hline
\end{tabular}

Table 6 shows that the majority of the respondents agreed that using podcasts was beneficial for their speaking skills, either in academic or in psychological aspects like their confidence, and motivation. However, from the previous result, it is stated that only a few respondents used podcasts for recording their own voice and for making their own speaking portfolio. The number even hit 32.5\%. Nevertheless, based on the information in Table 6, 75\% of the respondents agreed that it is an interesting idea to build a speaking portfolio by using podcast apps like Anchor or Spoon. This could mean that the respondents are interested in making one, but they have not managed to do it yet.

Table 6. Result of Students' Opinion on the use of Podcast in Learning Speaking Skill

\begin{tabular}{|c|c|c|c|c|}
\hline \multirow{3}{*}{ Item Description } & \multicolumn{4}{|c|}{ Attitude } \\
\hline & \multicolumn{2}{|c|}{ Positive } & \multicolumn{2}{|c|}{ Negative } \\
\hline & $\mathrm{f}$ & $\%$ & $\mathrm{f}$ & $\%$ \\
\hline $\begin{array}{l}\text { The exposure to diverse people talking through } \\
\text { podcasts give me the courage to speak more } \\
\text { confidently. }\end{array}$ & 192 & 90.6 & 20 & 9.4 \\
\hline $\begin{array}{l}\text { It is an interesting idea to build up a speaking } \\
\text { portfolio, using podcast app like Anchor or Spoon. }\end{array}$ & 159 & 75 & 53 & 25 \\
\hline $\begin{array}{l}\text { As time goes by, using podcasts (either listening to } \\
\text { it or actually using it to record my own speech) } \\
\text { makes me feel that I speak much smoother and } \\
\text { more fluent. }\end{array}$ & 181 & 85.4 & 31 & 14.6 \\
\hline $\begin{array}{l}\text { As I listen to podcast, I feel like a better speaker, } \\
\text { since I feel my speaking skill is improving. }\end{array}$ & 179 & 84.4 & 33 & 15.6 \\
\hline
\end{tabular}

From the result of the questionnaire as shown in Table 7 , it can be seen that the percentage of students agreeing that using podcasts could help their writing skill is just the 
average rate. Quite a consistent number of people have responded to each statement. This could mean that using podcasts for students to learn English independently do not have a direct impact on their writing but a gradual progression.

Table 7. Result of Students' Opinion on the use of Podcast in Learning Writing Skill

\begin{tabular}{lcccc}
\hline \multicolumn{1}{c}{ Item Description } & \multicolumn{3}{c}{ Attitude } \\
\cline { 2 - 5 } & \multicolumn{2}{c}{ Positive } & Negative \\
\cline { 2 - 5 } & $\mathrm{f}$ & $\%$ & $\mathrm{f}$ & $\%$ \\
\hline $\begin{array}{l}\text { As I listen to podcasts, sometimes I find some } \\
\text { grammatical structures, collocations or other points I } \\
\text { should remember that later on I should apply on my } \\
\text { writing. }\end{array}$ & 164 & 77.4 & 48 & 22.6 \\
\hline $\begin{array}{l}\text { Listening to podcasts often gives me ideas of what to } \\
\text { write. }\end{array}$ & 155 & 73.1 & 57 & 26.9 \\
\hline $\begin{array}{l}\text { I listen to podcasts and feel that I write much easier } \\
\text { and smoother. }\end{array}$ & 137 & 64.6 & 75 & 35.4 \\
\hline Podcast contributes to develop my writing style. & 138 & 65.1 & 74 & 34.9 \\
\hline
\end{tabular}

Quite the same amount of people responded to the questionnaire related to the reading skills part, with those to the writing skills part. This is considerably different compared to the spoken language for the development of listening and speaking skills, which gather more respondents agreeing with the statements. This could mean that using podcasts for learning English independently has much more impact on the skills related to spoken language rather than the ones dealing with written language.

Table 8. Result of Students' Opinion on the use of Podcast in Learning Reading Skills

\begin{tabular}{lcccc}
\hline & \multicolumn{3}{c}{ Attitude } \\
\cline { 2 - 5 } Item Description & $\mathrm{f}$ & $\%$ & $\mathrm{f}$ & Positive \\
\cline { 2 - 5 } & 175 & 82.5 & 37 & 17.5 \\
\hline $\begin{array}{l}\text { Using podcasts to listen to audiobooks feels like } \\
\text { reading itself, that we should keep paying attention if } \\
\text { we do not want to lose track of the storyline. }\end{array}$ & 155 & 73.1 & 57 & 26.9 \\
\hline Podcasts affects my reading skills in some ways. & 157 & 74.1 & 55 & 25.9 \\
\hline $\begin{array}{l}\text { I listen to podcasts and feel that I read much easier } \\
\text { and smoother. }\end{array}$ & 162 & 76.4 & 50 & 23.6 \\
\hline $\begin{array}{l}\text { As I listen to podcasts, I feel that my reading skill is } \\
\text { improving, since I get used to perceive English with } \\
\text { such exposure. }\end{array}$ & & & & \\
\hline
\end{tabular}

The data in Table 9 implied that using podcasts for learning English independently, as well as in independent study, played an important role for learners' development in learning the language. This is because they think it is a powerful tool for learning English outside of the classroom. This perspective about podcasts brings the learners to have a more positive mindset, attitude and belief that could affect their motivation in learning English.

Table 9. Result of Students' Opinion on the use of Podcast as an Adequate Tool for Learning English Independently

\begin{tabular}{lcccc}
\hline \multirow{2}{*}{ Item Description } & \multicolumn{3}{c}{ Attitude } \\
\cline { 2 - 5 } & \multicolumn{2}{c}{ Positive } & \multicolumn{2}{c}{ Negative } \\
\cline { 2 - 5 } & $\mathrm{f}$ & $\%$ & $\mathrm{f}$ & $\%$ \\
\hline $\begin{array}{l}\text { I believe that podcast is an adequate complementary } \\
\text { tool in learning English as an independent study. }\end{array}$ & 203 & 95.8 & 9 & \multirow{2}{*}{4.2} \\
\hline
\end{tabular}


This section presents the interpretation of the data analysis results as presented above. Four points are discussed, namely students' experience of using podcasts, the appealing characteristics of podcasts, the roles of podcasts in improving language skills and systems, and the use of podcasts as a tool for learning English independently. Each of the points are described below.

\subsection{Students' Experience on Using Podcast}

Majority of the respondents show a positive attitude towards the first question about listening to podcasts for fun, with the focus on learning English. It is supported by another research that has been done, proving that undergraduate students of L2 learners found "selfselect" podcasting experience enjoyable as well as influencing their listening strategies (Alm, 2013). Therefore, not only can it help students in their language learning, but also it can help listening for enjoyment. Chang and Millett (2014) also stated that podcast is one of the most favorite choices for listening practice since it is easy, comprehensible, and enjoyable for listening practice.

The second question is related to multitasking while listening to podcasts. Regarding this statement, only a little more than a half of the respondents reacted positively, which means only a little more than a half of them listen to podcasts while doing other activities such as jogging, cooking, painting, and so on. According to Coens, Degryse, Senecaut, Cottyn, and Clarebout (2011) on their experimental study investigating whether students can really listen to podcasts while walking or jogging, students can multitask as long as the content of the podcast is in the form of small chunks of contents, instead of longer contents which cover too much information. This could be an indication that the number of the respondents of this study either usually listen to longer podcasts or they just prefer to listen to anything while doing nothing to focus only on listening. It is common because some people do not like dividing their focus into more than one activity at the same time.

Regarding the features following podcasts like pre-listening activities, post-listening activities and transcript feature, most of the respondents admitted that they did not use them. This indicates that they may not want to do tasks other than listening to the sake of having fun. However, some others who choose to use the feature might want to study that topic or theme to the core, to train themselves, and to make sure that they understand and complete the podcast episode thoroughly. According to a study conducted by Fitria, Vianty, and Petrus (2015), the majority of their respondents (70\%) thought that pre-listening activity in podcasts helps to stimulate them to engage with the materials. As for the transcript, some students might use it if or in case they missed a line or two, or they want to catch up the phrases or expressions they misheard (Li, 2010). A case study of a Japanese student learning English as a foreign language also notes that a transcript is actually an important part of a podcast, which can be used for evaluating comprehension, comparing the understanding to the spoken discourse, and gauging how good the performance of the listener is (Cross, 2013).

As podcast media gets more popular in this decade, not only has it been used to share opinions or stories of diverse missions, but it has also been used for the purpose of language learning. Then, the term "thematic podcast" and "educational podcast" emerged, each of which with their different 'personalities' and aims. Some people prefer to use one or two of them for the sake of learning English. From the answers given by the students through the questionnaire, it can be seen that podcast has been used for extensive listening activities, 
listening to audiobooks, enlarging vocabularies, improving grammar competence, pronunciation, intonation, practice stress, and also for reading and writing skill. It is shown by the percentages in the findings that the majority of the respondents are already aware of that. The abundance of studies and research studying these things are the evidence implying why students are familiar with podcasts for those purposes.

However, the studies regarding the use of podcasts for practicing speaking and making self-made podcasts in podcasting platforms as speaking portfolios are still rare. There are only a few of them discussing podcasts as a tool in correlation with these purposes. Therefore, it is no wonder that the responses show that they are not really familiar with it, especially towards using podcasts for recording their own voices to practice speaking (52.4\% respondents) and towards making portfolios of their own voice recording (32.5\% of the respondents).

\subsection{The Appealing Characteristics of Podcast}

Not only is it useful for recording and sharing lecture materials, but podcasts are also useful for the use of language independent learning. It has lots of upsides which make it preferable for language learners. Some of its strengths are because podcasts are portable and easy to use. It is also enjoyable to help make learning less boring, provides interesting themes fitting to learners' interest, facilitates unconscious learning like what we do when we multitask, provides concise presentation of information, flexible to access anywhere and anytime, matches learners' learning style, provides meaningful context, keeps learners' attention by means of good arrangement, can be listened to repeatedly, and provides a chance of listening to authentic materials provided by native speakers. Towards these benefits, the majority of the respondents agreed, only $23.6 \%$ of them disagreed.

Podcast is considered portable and easy to use since it is readily available in all platforms (Ramli \& Kurniawan, 2017), even in music platforms like Spotify. It allows us to experience podcasting activity in easy steps. If we access podcasts on websites and open it through a web browser, we could just type the address of the podcast provider. If we prefer to listen to it through application, we could browse for other podcast suggestions. The overall process is a simple browsing, choosing, and clicking play button. A case study by Suparjan, Regina, and Sudarsono (2016) also found that the students they interviewed were very content with learning by using podcasts since it is easy to use and enjoyable. Another study by Darwis (2016) also demonstrated that podcasts are easy to use, with the majority of the students (83\%) showing positive response towards it.

Listening to podcasts is also such an enjoyable activity either during leisure time or while doing another activity. Suparjan et al. (2016) maintained that it provides flexibility and enjoyment since there is no time constraint and learners can study at their own pace. In line with that, Farshi and Mohammadi (2013) in their survey also concluded that podcasting activities help learning to be less boring.

One of the most likeable features about podcasts is its diverse themes and topics users can freely choose depending on what they want to listen to. This broad choice of topics allows learners to learn at their own pace and field of interest. Ramli and Kurniawan (2017) stated that the podcast brings various engaging topics and themes that could enrich students' insight.

Providing media that match learners' learning style and preference is also one of the favorite features especially for auditory learners. In the present study, most of the students 
(77.4\%) agreed with this aspect. In a study, Harris and Park (2008) also stated the same opinion, that a podcast is a potential medium to change the learning experience, since it facilitates information delivery and organization tailored to learners' learning style and individual preferences.

From the result of the questionnaire, we can see that the majority of students (92.5\%) agree that podcasts provide meaningful context, and $97.6 \%$ of them also agree that it provides a chance of listening to authentic materials from native speakers. In line with this, Gromik (2008) maintained that podcasting activities allow learners to interact with full access to authentic resources in context. Besides, it also offers real-life listening resources that could be benign for the English learners of foreign languages (Abdulrahman, Basalama, \& Widodo, 2018).

Almost $90 \%$ of the respondents in this study also agree that the way the information is arranged in the podcasts helped keep their attention. Some podcast broadcasters might speak up freely and randomly, but it depends on their contents and purpose. However, most of the podcast creators prepare an outline of what they are going to talk about during the recording. This prevents them from getting sidetracked so that the listeners could stay still and pay attention for long minutes. A study by Asoodar et al. (2014) demonstrates that only $22 \%$ of the respondents of the survey did not agree with a statement stating that the way the information is arranged in the podcasts helped keep their attention. Bolliger, Supanakorn, and Boggs (2010). also maintained that many of the students they observed thought that the structure and quality of podcasts assisted them to gain and hold their attention. Another research conclusion by Ningsih, Ulfa, and Mulyono (2020) suggests that podcasts have potential to be used in language learning environments for developing English competencies of the learners.

\subsection{The role of podcast in improving Language Skills and Language Systems}

On research concerning podcasts as a facilitator of proper pronunciation, the result shows that the activity of podcasting can potentially increase students' performance in pronunciation skill, aside from its impact to the language development in general (Almaqrn \& Alshaheb, 2017). Not only because learners can imitate word pronunciation they heard, but there are also lots of podcast providers providing pronunciation-specific content, just like pronunciation training, teaching various components of pronunciation. It is true that while we speak, it is difficult to hear our own pronunciation errors and prosody mistakes (Phillips, 2017), so listening to these kind of pronunciation-specific podcast contents or just merely listening to any podcast can truly help learners to fix and improve their pronunciation. A classroom action research conducted by Sari and Riyani (2020) on improving students' pronunciation by utilizing podcasts yielded a similar result. On the students' post-test, they can pronounce words significantly better than during the pre-test after only 3 meetings. Asoodar et al. (2014) conducted an in-depth interview towards the EFL students regarding this matter. In the interview, a student said that the podcast has helped him a lot with his pronunciation skill.

In regards to vocabulary acquisition, podcast offers limitless resources to make use of, and it is the users' task to be able to know how to make use of it optimally. When we listen to podcasts, there surely are the meanings of words that we do not understand. So, we are also trained to use our brain digging up memories and other words related to them, to make a guess or inference. Fortunately, podcasts offer this training method since it always has meaningful 
context in each of its episodes. Therefore, taking up or remembering new vocabularies would be easier this way. A study by Fitria et al. (2015) shows that podcasts are thought by the students as an effective learning tool for learning English in general, including vocabulary. Another study by Nemeth and Bueno-Alastuey (2020) also confirms that podcasts can enhance receptive vocabulary knowledge. However, to utilize podcasts optimally for vocabulary acquisition, it is important for the learners to select podcasts that are likely to repeat the same vocabularies, so they can hear those words over and over again. This could be done by selecting podcast materials with consistent themes (Meier, 2015).

Being able to acquire and imitate the natural flow of speech and natural English expressions are also the upsides of podcasts. More than $94 \%$ of the respondents of this research agree with this. It is because podcasts provide students with authentic materials spoken by the native speakers themselves, the ones who know how to use their languages like they do. There are sometimes formal or colloquial expressions that non-native speakers are not familiar with like phrasal verbs, interjections, and many more. From the podcast, we can also learn how to speak with the right intonation and flow of speech like the natives do.

Another one included as an upside of podcast based on the result of this research is the fact that it helps learners trained to make inferences of guesses of the words they do not know the meaning of while listening to the listening sources. When someone catches new words, the choices are checking their dictionaries or continuing to listen to the podcast and guess what that might mean based on linking or associating with the words they have already known and the sentences they understand. It is supported by a research done by Bidabadi and Yamat (2014) showing that freshmen they studied who employed this method reported that the known words did help them to guess the meaning of unknown words.

Most respondents of this research (95.3\%) found that listening to podcasts can enhance their listening skill, with $87.7 \%$ reported that it helps them understand long utterances, conversations and monologues much better. Extensive studies have studied the benefit of podcasts, since it has great deals of association with listening skill. One of them is demonstrated by Al Qasim and Al Fadda (2013), showing results that utilizing podcasts can improve students' listening comprehension, and even motivation and attitude towards the use of it, rather than the traditional classroom instruction. Students' perceptions examined by Md Masudul; Hasan and Hoon (2012) resulted in $76 \%$ of all the observed students showing a positive attitude towards the techniques of developing listening skill by using podcasts. A two-cycle classroom action research (CAR) by Wiyanah (2015) also showed the result that there is an improvement between students' pre-test and post-test score after employing podcasts in their learning. The students then can understand more communicative use of English, as well as develop their skill in listening to native speakers' correct pronunciation, writing, and extended vocabularies. A recent experimental study by Abdulrahman et al. (2018) also showed that applying podcasts has a significant impact on students' listening comprehension, with the experimental class scoring higher in the post-test. Most of the students also feel more motivated in learning English by using podcasts due to the features it provides.

The majority of respondents of this research (84.4\%-85.4\%) admitted that podcasts can improve their speaking by listening to a more fluent and better speaker. In their quasiexperimental study, Fitria et al. (2015) found that there were convincing differences between students who were taught by utilizing podcasts and those who were not, in terms of their 
listening and also speaking achievement. It is even suggested that those two skills are integrated in learning activity, either classically or independently.

Another study conducted by Alfa (2020) also showed that podcasts contribute to students' speaking achievement, since it provides authentic materials. It suggests using podcasts in the instructional activity in class as well as assigning students using it in their homes so they are able to practice autonomously and independently. It is also argued that the use of podcasts to record students' voices to make self-made podcasts and building up speaking portfolios is less appealing. Only $52.4 \%$ of the student respondents use podcasts to record their own voice and only $32.5 \%$ of them use podcasts to make portfolios of their own recording. Nevertheless, in this part of the questionnaire $75 \%$ of the respondents believe that building up speaking portfolios, using podcast apps like Anchor or Spoon is an enthralling idea. From this, it can be concluded that although most of the students do not use podcasts for the abovementioned purposes, more students think that utilizing podcasts for those purposes is an intriguing idea. Only, they have not managed to make use of it yet.

The remarks about making self-made podcasts can help students in their speaking ability is supported by the experimental study conducted by Farangi et al. (2015) showing that the learners employing student-made podcasts as a treatment in the experiment group outperformed the learners in the other group not implementing one. In line with this invention, Cepik and Yastibas (2013) also maintained the same idea. They argue that e-portfolio can be utilized in learning speaking since it can influence the learners speaking skill effectively. In another study, Huang and Hung (2010) even stated the reasons in much more detail. It is maintained that e-portfolio can help students to self-assess weaker areas in their own speaking that undermine their performance. Other than that, making e-portfolios offers learners to experience additional opportunities for oral practice without time and space constraint in the process. The study also reports that one of the students even argued that by making self-made podcasts and e-portfolio, she has developed the habit of thinking in English, and she became way more fluent.

The last thing to be addressed is speaking confidence. $90.6 \%$ of the total student respondents reported that the exposure to diverse people talking through podcasts give them the courage to speak more confidently. In other words, it can suppress their anxiety and make them feel motivated to speak up. It is supported by a study carried out by Cepik and Yastibas (2013) that by practicing speaking by making an e-portfolio, students can boost their selfconfidence, motivation, and alleviate speaking anxiety. Also, Huang and Hung (2010) similarly argued that e-portfolio is a good tool for speaking practice since it allays speaking anxiety of talking directly in front of people, with the fear of the audience challenging their point of view as they speak. A student who participated in an interview managed by Phillips (2017) also maintained that making a self-made podcast or e-portfolio is a great opportunity to improve speaking skill, since they see a lot of benefits in producing podcasts.

The results of the questionnaire shows that a little bit more than half of the respondents agree that podcasts can help them in their writing. $77.4 \%$ of them admitted that sometimes they find some grammatical structures, collocations or other points they should remember so later on they can apply it on their writing; $73.1 \%$ of them agree that sometimes podcast give them idea of what to write; $64.6 \%$ of them thought they feel much easier and smoother as they listen to podcast; and $65.1 \%$ of them thought that podcast contributes to develop their writing 
skill. These data are all in agreement with the previous study presented by Suparjan et al. (2016) stating that podcasts can help students to improve English skills, possibly also including writing skill. In the interview, some students stated that they did not really feel significant improvement on their writing after the podcast treatment. However, one of the students in the study stated that albeit writing is not improved as significantly as the other skills, they thought that the writing skill must be automatically improved as well. It is in line with another study by Zahan Chowdhury \& Haque (2019) showing that only a small number of the respondents thought that podcasting can affect their writing skill. Kohar, Salam, and Sumarni (2014) argued that although there was no direct impact on students' writing skill, the skill must be improving gradually.

One of the usages of podcasts is for listening to audiobooks. It is an engaging alternative for those who are too busy to open books and read, or too tired after a long day at work or school. Recently, people started to listen to audiobooks, since it is a simple alternative way to read that someone can do while doing other activities such as cooking, jogging, driving on the way to work, and many more. This seems to be the most likely reason why most of the respondents chose to use it as listening practice in their independent learning. According to the data, even though only $59 \%$ of them listen to audiobooks, $82.5 \%$ of the respondents thought that listening to podcasts as audiobooks feels like reading itself, that is, one should keep paying attention if one does not want to lose track of the storyline. This could indicate that half of them do not listen to audiobooks, since it is quite complicated to keep paying attention and not to lose track of the storyline.

Nonetheless, most of the respondents (73.1\%-76.4\%) thought that podcasting for learning English independently contributes to their reading skill improvement. It helped them to read much easier and smoother, as they get used to being exposed to English with such exposure. This is also supported by some prior studies. One of them is a study conducted by Zahan Chowdhury \& Haque (2019), maintaining that the activity of podcasting can help the students in their reading and vocabulary skills to some extent. This is also consistent with a research by Suparjan et al. (2016) concluding that the students' skill of reading is significantly developed through the use of podcasts as learning media.

\subsection{Podcast as a Tool for Learning English Independently}

In addition to the advantages that have been explained in the previous sections, there is more literature proving that using podcasts is considered to be a powerful tool to enhance learners' English skills. A descriptive study by Norhayati and Jayanti (2020) involved students randomly selected from five universities to show that podcasts are one of the effective media for learning English. It can be utilized by any students to learn English as an autonomous learning. It is concluded that podcasts can help students not only in their listening skills as many believed so. It also helps to boost their motivation, enhance their language systems, as well as speaking, reading, and writing skills in their independent learning

\section{Conclusion}

Data analysis results in this study have shown that most of the respondents listened to podcasts for fun. Only a few of them usually used podcast's pre-listening activities, postlistening activities and transcription features. They enjoyed using podcasts in their independent learning mostly because it is portable, simple, enjoyable, accessible. Also, 
podcasts provide various interesting topics to learn, concise wrap of information, meaningful context, and a chance to listen to authentic materials presented by native speakers.

It is a common phenomenon that students experience using podcasts to practice listening, expand vocabulary, and practice other language systems like intonation, pronunciation, stress, and grammar. However, only a few respondents admitted to using podcasts to practice speaking, and only a half of them used it with the intention to improve reading and writing skills.

A high number of respondents also responded positively to the use of podcasts in learning language systems, listening skills and speaking skills, compared to the response towards the use of podcasts for reading and writing skills. This shows that using podcasts for learning English independently to hone speaking skills, listening skills, and language systems is more preferred than utilizing it for honing reading and writing skills.

Finally, most of the students have positive opinions towards the utilization of podcasts for learning English independently, either in their language systems, listening skill, speaking skill, reading skill and writing skill. Also, almost all of the respondents believe that podcasts are an adequate complementary tool in learning English independently.

\section{References}

Abdulrahman, T. R., Basalama, N., \& Widodo, M. R. (2018). The impact of podcasts on EFL students' listening comprehension. International Journal of English Linguistics, 8(6), 122-130. https://doi.org/10.5539/ijel.v8n6p122

Al Qasim, N., \& Al Fadda, H. (2013). From CALL to MALL: The effectiveness of podcast on EFL higher education students' listening comprehension. English Language Teaching, 6(9), 30-41. https://doi.org/10.5539/elt.v6n9p30

Alfa, R. R. (2020). Using podcast as authentic materials to develop students' speaking skill. JELLT (Journal of English Language and Language Teaching), 4(1), 65-74.

Alm, A. (2013). Extensive listening 2.0 with foreign language podcasts. Innovation in Language Learning and Teaching, 7(3), 266-280. https://doi.org/10.1080/17501229.2013.836207

Almaqrn, R. K., \& Alshaheb, A. M. (2017). EFL learners' attitudes towards the proper pronunciation of English and podcasts as a facilitator of proper pronunciation. Arab World English Journal (AWEJ), 8(1), 208219.

Asoodar, M., Marandi, S. S., Vaezi, S., \& Desmet, P. (2014). Podcasting in a virtual English for academic purposes course: learner motivation. Interactive Learning Environments, 24(4), 875-896. https://doi.org/10.1080/10494820.2014.937344

Bidabadi, F. S., \& Yamat, H. (2014). Strategies employed by Iranian EFL freshman university students in extensive listening: a qualitative research. International Journal of Qualitative Studies in Education, 27(1), 23-41. https://doi.org/10.1080/09518398.2012.737042

Bolliger, D. U., Supanakorn, S., \& Boggs, C. (2010). Impact of podcasting on student motivation in the online learning environment. Computers and Education, 55(2), 714-722. https://doi.org/10.1016/j.compedu.2010.03.004

Cepik, S., \& Yastibas, A. E. (2013). The use of e-portfolio to improve English speaking skill of turkish EFL learners. The Anthropologist, 16(1-2), 307-317. https://doi.org/10.1080/09720073.2013.11891358

Chang, A. C. S., \& Millett, S. (2014). The effect of extensive listening on developing L2 listening fluency: Some hard evidence. ELT Journal, 68(1), 31-40. https://doi.org/10.1093/elt/cct052

Coens, J., Degryse, E., Senecaut, M. P., Cottyn, J., \& Clarebout, G. (2011). Listening to an educational podcast while walking or jogging: Can students really multitask? International Journal of Mobile and Blended Learning, 3(3), 23-33. https://doi.org/10.4018/jmbl.2011070102 
Cross, J. (2013). Promoting autonomous listening to podcasts: A case study. Language Teaching Research, 18(1), 8-32. https://doi.org/10.1177/1362168813505394

Darwis, R. (2016). Students ' perceptions towards the use of podcast in learning English: A case study of the second grade students at one high school in Bandung. Journal of English and Education, 4(2), 80-100.

Farshi, N., \& Mohammadi, Z. (2013). Use of podcasts in effective teaching of vocabulary: Learners' attitudes, motivations and limitations. Theory and Practice in Language Studies, 3(8), 1381-1386. https://doi.org/10.4304/tpls.3.8.1381-1386

Fitria, U., Vianty, M., \& Petrus, I. (2015). Using podcast to improve students' listening and speaking achievements. The Journal of English Literacy Education: The Teaching and Learning of English as a Foreign Language, 2(1), 55-68.

Gromik, N. (2008). EFL learner use of podcasting resources: A pilot study. JALT CALL Journal, 4(2), 47-60.

Harris, H., \& Park, S. (2008). Educational usages of podcasting. British Journal of Educational Technology, 39(3), 548-551. https://doi.org/10.1111/j.1467-8535.2007.00788.x

Hasan, M. M., \& Hoon, T. B. (2012). ESL learners' perception and attitudes towards the use of podcast in developing listening skills. The English Teacher, 41(2), 160-173.

Huang, H.T.D., \& Hung, S.T.A. (2010). Implementing electronic speaking portfolios: Perceptions of EFL students: Colloquium. British Journal of Educational Technology, 41(5), 84-88. https://doi.org/10.1111/j.1467-8535.2009.00996.x

Kohar, E., Salam, U., \& Sumarni. (2014). Students' perception towards the use of podcast for learning English. Jurnal Pendidikan Dan Pembelajaran Khatulistiwa, 3(12). Li, H. C. (2010). Using podcasts for learning English: Perceptions of Hong Kong Secondary 6 ESL students. Début: The Undergraduate Journal of Languages, Linguistics and Area Studies, 1(2), 78-90.

Meier, A. (2015). L2 incidental vocabulary acquisition through extensive listening to podcasts. Working Papers in TESOL \& Applied Linguistics, 15(2), 72-84.

Nemeth, K., \& Bueno-Alastuey, M. C. (2020). Quizlet and podcasts: Effects on vocabulary acquisition. Computer Assisted Language Learning, 1-30. https://doi.org/10.1080/09588221.2020.1802601

Ningsih, S. K., Ulfa, N., \& Mulyono, H. (2020). An Exploration of Indonesian University Students ' Perception of the Use of Podcast for Learning of English as a Foreign Language. 41(11), 21.

Norhayati, N., \& Jayanti, S. (2020). Pemanfaatan teknologi untuk mendukung kegiatan belajar secara mandiri (studi kasus: penggunaan podcast oleh mahasiswa di kota Palangkaraya). Jurnal Humaniora Teknologi, 6(1), 29-36. https://doi.org/10.34128/jht.v6i1.73

Phillips, B. (2017). Student-produced podcasts in language learning - exploring student perceptions of podcast activities. IAFOR Journal of Education, 5(3), 157-171. https://doi.org/10.22492/ije.5.3.08

Rahimi, M., \& Katal, M. (2012). The role of metacognitive listening strategies awareness and podcast-use readiness in using podcasting for learning English as a foreign language. Computers in Human Behavior, 28(4), 1153-1161. https://doi.org/10.1016/j.chb.2012.01.025

Ramli, A. M., \& Kurniawan, E. H. (2017). The use of podcast to improve students' listening and speaking skills for EFL learners. Advances in Social Science, Education and Humanities Research, 145, 189-194. https://doi.org/10.2991/iconelt-17.2018.42

Sari, A. I., \& Riyani. (2020). Penggunaan podcast untuk memperbaiki pengucapan (pronunciation) mahasiswa dalam berbicara bahasa Inggris. Research Fair Unisri 2019, 4(1).

Suparjan, Regina, \& Sudarsono. (2016). Students' attitudes towards the use of podcast for English language learning: A case study at Tanjungpura University. Jurnal Pendidikan dan Pembelajaran Untan, 5(3).

Wiyanah, S. (2015). Improving listening skill using podcast for English Department students of Upy. Seminar Nasional Universitas PGRI Yogyakarta. Retrieved from http://repository.upy.ac.id/375/1/FK10_Sri Wiyanah FIX 58-67.pdf

Zahan Chowdhury, N., \& Haque, F. (2019). Teachers and learners' perception towards the use of podcasts for learning English at the undergraduate level in Bangladesh: An empirical study. International Journal of Advanced Research, 7(8), 505-516. https://doi.org/10.21474/ijar01/9527 